Original Article

\title{
ISOLATION OF CYTOTOXIC CONSTITUENT FROM BIOACTIVITY GUIDED FRACTION OF ALYSICARPUS MONILIFER L. (DC.)
}

\author{
PURVI H. KAKRANI'1, HARISH KAKRANI', MANAN RAVAL2*
}

1Department of Pharmacognosy, Shivam Pharmacetical Studies and Research Centre, Opposite Swaminayan Vidyapith, Anand-Sojitra Road, Valasan, Anand 388326, 2Department of Pharmacognosy, Ramanbhai Patel College of Pharmacy, Charotar University of Science and Technology (CHARUSAT), Changa, Dist. Anand, Gujarat, India

Email: mananraval.ph@charusat.ac.in

Received: 04 May 2019 Revised and Accepted: 15 Jul 2019

ABSTRACT

Objective: Alysicarpus monilifer (Family Papilionaceae) has been used in the Indigenous system of medicine in tumor removal. The present study was designed to isolate and identify the constituent responsible for cytotoxic (anti-tumor) effects of the plant Alysicarpus monilifer.

Methods: The plant was powdered and extracted to give a methanolic extract. Initially, Hexane, chloroform, ethyl acetate and methanolic fractions of the methanolic extract of the plant were subjected to cytotoxic screening using cell line based assay (MTT assay and NRU assay). The chloroform fraction showed significant cytotoxicity, so it was further subjected to column chromatography, to separate the cytotoxic phytoconstituent. The cell lines selected were breast cancer cells (MCF-7 and MDA-MB-468) and Liver cancer cells (HepG2 and HLE cell). Results were calculated as percentage growth inhibition with respect to untreated (control) cells versus treated cells.

Result: A triterpene, Betulinic acid, was isolated from the aerial parts of Alysicarpus monilifer. The cytotoxic activity of the identified compound against MCF-7, MDA-MB-231, HLE and HepG2 cells was also found to be highly significant with $90 \%$ growth inhibition.

Conclusion: The triterpene was identified to be betulinic acid, to which the cytotoxic activity can be attributed. It is a first report of isolation of betulinic acid from the Alysicarpus species.

Keywords: Alysicarpus monilifer, Betulinic acid, Pentacyclic triterpenoid, Phytochemistry, In vitro cytotoxicity, Phytopharmacology

(c) 2019 The Authors. Published by Innovare Academic Sciences Pvt Ltd. This is an open access article under the CC BY license (http://creativecommons.org/licenses/by/4.0/) DOI: http://dx.doi.org/10.22159/ijpps.2019v11i8.33931

\section{INTRODUCTION}

Alysicarpus monilifer L.(DC.) (Papilionaceae), commonly known as Juhi ghas (Hindi) or Samervo (Gujarati), is a turf forming legume [1, 2]. In India it is found to be distributed throughout the plainsBombay, Madras, Jammu, Punjab, Gujarat (except Kutch and Bulsar), Uttar Pradesh and Madhya Pradesh [3].

The plant has been used in indigenous system of medicine as an antidote to snake bite $[4,5]$, anti-inflammatory and in stomach-ache ${ }^{1}$. The leaves are used in jaundice and in fever $[6,7]$. It is also used as a diuretic, in tumor removal and in skin diseases [8-11].

The plant was found to contain C-glycosyl flavones such as vitexin and isovitexin triterpene named as Alysinol (3-alpha, 22betadihydroxyolean-12-ene) along with known compounds like usnic acid, methyl 2,4-dihydroxy-3,6-dimethyl benzoate, 3-hydroxy benzoic acid, stigmasterol, poriferasterol and ursolic acid, carbohydrates, fixed oils, phenolics and tannins from the studies [12-15]. Methanolic extracts of aerial parts of A. monilifer demonstrated promising analgesic and anti-inflammatory activity $[16,17]$. The methanolic extract was also shown to protect liver function and reduce oxidative stress [12]. Karthikeyan (2017) demonstrated the prominent anti-diabetic activity of $A$. monilifer streptozotocin-induced diabetic rats [18].

The aerial parts of $A$. monilifer are indicated as anti-tumor agents in ethnobotany, but this has not been proved pharmacologically. So it was thought worthwhile to carry out investigations for the same. It was further proposed to isolate phytoconstituents responsible for cytotoxic activity from the fractions of methanolic extracts of aerial parts of the plant by adopting bioactivity guided fractionation approach. These phytoconstituents were planned to be characterized chemically using spectral methods.

\section{MATERIALS AND METHODS}

Authentication of plant material

The fully grown plants of A. monilifer L.(DC.) was collected from New Vallabh Vidyanagar region of Anand. It was collected from July to October, when flowering and fruiting season is observed. The authentication was carried out by Dr. Suman Chandra Sharma, Taxonomist, Department of Botany, Government Dungar College, Bikaner, Rajasthan. The voucher specimen was deposited with Department of Pharmacognosy, Ramanbhai Patel College of pharmacy, Changa (CHARUSAT) with voucher specimen number 2012/PK/AM.

\section{Preparation and collection of plant material}

Dried aerial parts of $A$. monilifer were used for phytochemical studies. The aerial plant parts were dried under shade and powdered coarsely, stored in airtight containers and used for further studies.

\section{Extraction}

The shade dried, powdered aerial parts of A. monilifer $(20 \mathrm{~kg})$ were soaked in methanol and the extraction process repeated thrice. The methanolic extract (AM-1) obtained was evaporated under reduced pressure to obtain greenish gummy material $(950 \mathrm{~g})$, which was then dissolved in water and extracted with nhexane to yield hexane fraction (AM-2). The water layer further partitioned with chloroform to yield a chloroform fraction (AM-2). The aqueous layer was partitioned with ethyl acetate to yield ethyl acetate fraction (AM-3). The leftover aqueous layer was evaporated to give a residue, which was dissolved in methanol to yield a methanolic fraction (AM-4) $[19,20]$. The extraction can be schematically represented as in fig. 1 


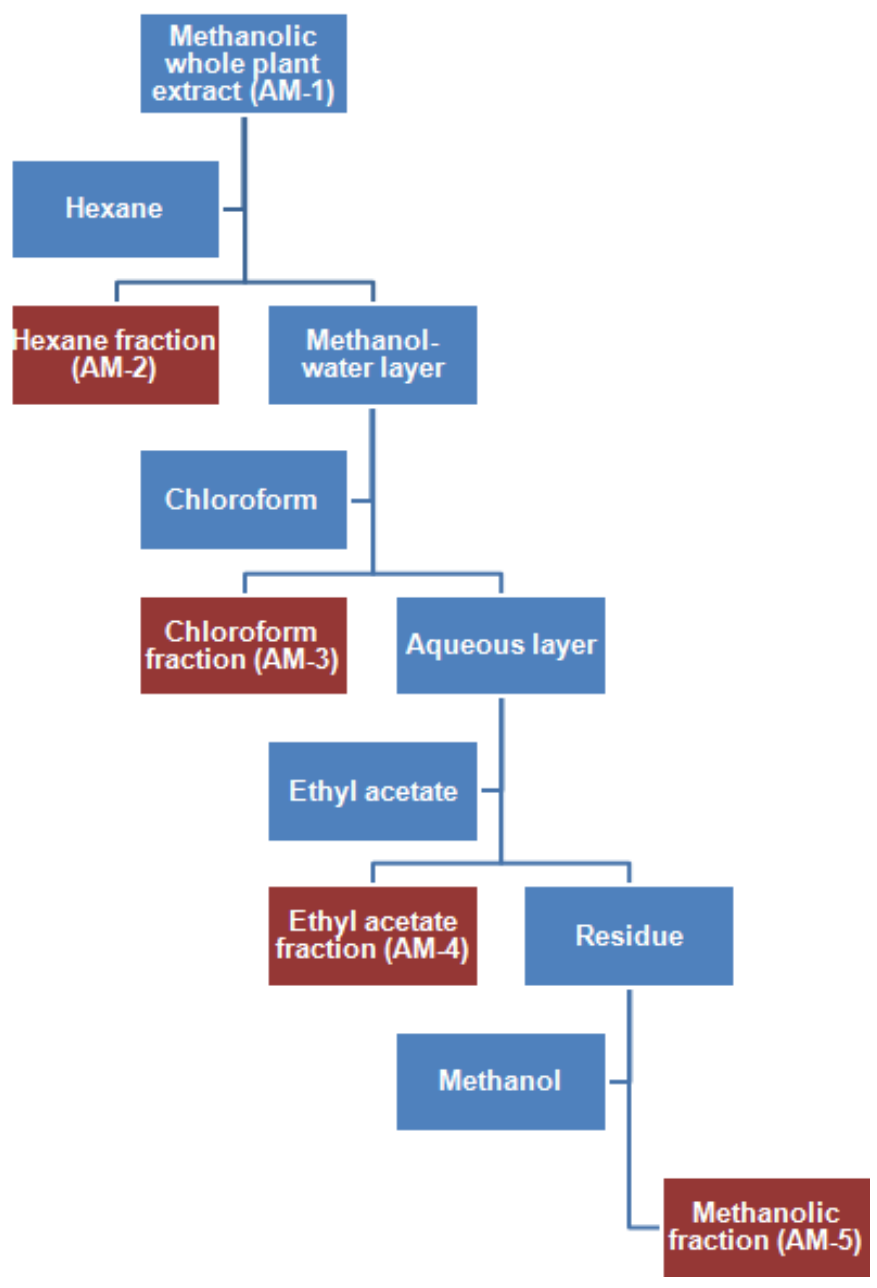

Fig. 1: Fractionation scheme of AM-1 of A. monilifer

\section{Bioactivity-guided fractionation}

In a biological activity-guided fractionation approach, the methanolic (AM-1) extract was investigated for cytotoxic activity against four cancer cell lines. A series of eight dilutions of AM-1 (10$500 \mu \mathrm{g} / \mathrm{ml}$ ) was used to determine the concentration-dependent cytotoxic effect on four cancer cell lines (MCF-7, MDA-MB-231, HepG2 and HLE cell lines) after $24 \mathrm{hr}$ treatment, using two cytotoxicity assays; MTT and neutral red uptake (NRU) assays.

The direct methanolic extract (AM-1) of the plant was partitioned into Hexane (AM-2), Chloroform (AM-3), ethyl acetate (AM-4) and methanolic (AM-5) fractions (fig. 1). These fractions were tested, individually, for cytotoxic activity on all four cancer cell lines (MCF7, MDA-MB-231, HepG2 and HLE cell lines). For each fraction, a final concentration of $200 \mu \mathrm{g}$ per well was prepared in the medium containing DMSO (Dimethyl sulfoxide, maximum: $0.01 \%$ ) and tested using MTT and NRU assays using the same protocol conditions as in the case of AM-1.

\section{Purification of AM-3}

AM-3 was biologically more active than the other fractions. So purification of AM-3 was carried out using column chromatography. Purification of AM-3 in column chromatography with silica gel employed an isocratic elution system of ethyl acetate: hexane: acetone $(7: 3: 5)$ as eluting solvent. This resulted in the isolation of a triterpenoid compound AMB 004.

\section{Assessment of purity of AMB 004}

The purity of the AMB 004 was checked by performing HPLC and TLC. The compound had a characteristic peak under optimized chromatographic conditions in HPLC, with $98.2 \%$ purity calculated by area normalization. While in TLC, a single spot was obtained in the mobile phase.

\section{Cytotoxicity assays}

Cellular damage will inevitably result in a loss of the ability of the cell to maintain and provide energy for metabolic cell function and growth. A number of methods have been developed to study cell viability and proliferation in cell populations. One parameter used as the basis for colorimetric assays is the metabolic activity of viable cells. Both qualitative and quantitative cell viability assays have been developed in a microplate format (96-well plates).

\section{Human cell lines collection}

The cell lines MCF-7, MDA MB-231, HepG2 and HLE cell lines were selected for the studies. MCF-7 is a human breast estrogen-dependent cancer cells. MCF-7 is short form from of Michigan Cancer Foundation-7 (An institute in Detroit) where the cell line was originally established by Herbert Soule and co-workers in the year 1973. MDA-MB-231 stands for M. D. Anderson-metastatic breast-231. It is human breast cancer cells, which lacks oestrogen receptors i.e. it is estrogen-independent adenocarcinoma. HepG2 is a human liver cancer cell line; while HLE cell line is undifferentiated human Hepatoma cells.

\section{Procurement and culturing of cell lines}

The cell lines, MCF-7, MDA MB-231, HepG2 and HLE cell lines were procured from the National Centre for Cell Science, Pune, India. The cell lines were grown in an incubator at $37{ }^{\circ} \mathrm{C}$ in an atmosphere that contains $5 \% \mathrm{CO}_{2}$ and $90 \%$ Relative humidity. The cells were maintained in the form of monolayer in Eagle's minimum essential 
media (EMEM) (procured from Sigma Aldrich), supplemented with $10 \%$ fetal calf serum, 20 mmol l-glutamine, $2 \%$ penicillinstreptomycin, and $0.2 \%$ gentamicin in a carbon dioxide incubator $\left(37{ }^{\circ} \mathrm{C}, 5 \% \mathrm{CO}_{2}, 90 \%\right.$ Relative Humidity). Cells were passaged routinely. The cells after sub-passage were harvested from the flask by treatment with trypsin $(0.05 \%$ in PBS (pH 7.4) containing $0.02 \%$ EDTA). Cells with viability of more than $98 \%$ (as determined by trypan blue exclusion) were used for determination of cytotoxicity.

Cytotoxicity of fractions and compound was assessed using MTT assay and Neutral Red uptake (NRU) assay. The methodologies adopted are described in brief. [22, 23]

\section{Preparation of test solution}

A series of eight dilutions, i.e. 10, 25, 50, 100, 200, 300, 400 and 500 $\mu \mathrm{g} / \mathrm{ml}$ concentrations of AM- 1 were prepared in the medium containing DMSO. Cells were seeded into 96-well cell culture plates at a density of $1 \times 10^{4}$ cells per well in $100 \mu$ laliquots of the medium. The cells were allowed to attach for $24 \mathrm{hr}$ in a carbon dioxide incubator $\left(37^{\circ} \mathrm{C}, 5 \% \mathrm{CO}_{2}, 90 \% \mathrm{RH}\right)$. After a $24 \mathrm{hr}$ exposure period, the $\%$ inhibitions were determined using two colorimetric assays; namely the MTT assay and NRU assay.

As the plant showed moderate to good cytotoxic activity, the next step was to find out the cytotoxic fraction from the above extracts. Hexane (AM-2), Chloroform (AM-3), Ethyl acetate (AM-4) and Methanol (AM-5) fractions from direct methanolic extract (AM-1) of A. monilifer were tested, individually, for cytotoxic activity on four cancer cell lines (MCF-7, MDA-MB-231, HepG2 and HLE cell lines).

For each fraction, a final concentration of $200 \mu \mathrm{g}$ per well was prepared in the medium containing DMSO (Dimethyl sulfoxide, maximum: $0.01 \%$ ) and tested using MTT and NRU assays using the same protocol conditions as in the case of AM-1. AM-3 was found to possess the most significant cytotoxic activity. AM-3, on purification using column chromatography, gave a triterpenoidal compound. This compound was identified as Betulinic acid with the help of spectral studies.

Cytotoxic activity of compound Betulinic acid from A. monilifer was evaluated at $24 \mathrm{hr}$ and $48 \mathrm{hr}$ in order to establish a time-dependent as well as concentration-dependent cytotoxic effect. Actinomycin-D $(4 \mu \mathrm{M})$, Tamoxifen $(5 \mu \mathrm{M})$ and Anastrozole $(5 \mu \mathrm{M})$ were used as standards. A serial dilution of eight concentrations $(0.78,1.56,3.12$, $6.25,12.5,25,50,100 \mu \mathrm{M}$ ) for isolated compound Betulinic acid was tested using MTT and NRU assays, for $24 \mathrm{hr}$ and $48 \mathrm{hr}$ treatments.

\section{[3-(4,5-dimethylthiazol-2-yl)-2,5-diphenyltetrazolium bromide] assay (MTT assay)}

According to the method described by Borenfreund et al., [22] growth of cancer cells was quantified. The cells, grown in a 96 well tissue culture plate, were exposed to the drug in question and incubated for about $24 \mathrm{hr}$. Following the incubation period, cells were washed twice with PBS (Phosphate buffer saline). Next, a $10 \mu \mathrm{l}$ of MTT reagent (5 mg/ml in PBS) was added to each well including the blanks, which contained medium only. Cells were incubated with this yellow MTT solution for approximately $4 \mathrm{hr}$. After this incubation period, purple formazan salt crystals are formed. These salt crystals are insoluble in aqueous solution but were solubilized by incubating the plates with the solubilizing solution i.e. Dimethyl Sulfoxide (DMSO) (100 $\mu \mathrm{l} /$ well; maximum: $0.01 \%)$ and overnight in a humidified atmosphere $\left(37{ }^{\circ} \mathrm{C}, 5 \%\right.$ Carbon dioxide). The solubilized purple formazan product was spectrophotometrically quantified. The effect of plant extracts on cancer cells was quantified as the percentage of control absorbance of reduced dye at $550 \mathrm{~nm}$ on a microplate reader. Each experiment was repeated three times $(n=3)$. Mean and standard deviation were calculated between the three experiments. Results were calculated as percentage growth inhibition, untreated (control) cells versus treated cells according to the following formula:

$$
\% \text { Growth Inhibition= } \frac{\text { Control-Actual absorbance }}{\text { Control }} \times 100
$$

Where: Control $=$ absorbance of untreated cells after subtracting absorbance of media
Actual absorbance $=$ absorbance of treated cells at a particular concentration of testing sample after subtracting the absorbance of media

\section{Neutral red uptake (NRU) assay}

In each well of a 96-well cell culture plate, serial dilutions of each sample, understudy and standard were added in the cell culture medium containing cancer cell lines. An aliquot of $1 \times 10^{4}$ cells was placed in each well of a 96-well cell culture plate, making a total volume of $200 \mu \mathrm{l}$ in each well. These dosed cells were incubated for $72 \mathrm{hr}$ in humidified $5 \% \mathrm{CO}_{2}$ atmosphere at $37{ }^{\circ} \mathrm{C}$. The medium was removed by decantation and $200 \mu \mathrm{l}$ fresh medium containing 50 $\mu \mathrm{g} / \mathrm{ml}$ Neutral red was added to each well. This was incubated for an additional $3 \mathrm{hr}$ at $37{ }^{\circ} \mathrm{C}$ in $5 \% \mathrm{CO}_{2}$ atmosphere. This dye medium was then removed by decantation and each well was then washed rapidly with pre-warmed $200 \mu \mathrm{l}$ PBS, followed by addition of $200 \mu \mathrm{l}$ of acetic acid-water-ethanol in water (1:49:50). This mixture acts as a fixative agent, which allows the Neutral Red dye to fix with the cells. The cells were allowed to attach for $24 \mathrm{hr}$ at $37^{\circ} \mathrm{C}, 5 \% \mathrm{CO}_{2}$ in air in a humidified atmosphere.

The plates were kept at room temperature for $15 \mathrm{~min}$ so as to extract the dye and then the plates were covered in foil and placed on a plate shaker for $30 \mathrm{~min}$ to extract neutral red from the cells and form a homogeneous solution. The absorbance of the wells was measured at $540 \mathrm{~nm}$ spectrophotometrically within $60 \mathrm{~min}$. Each experiment was repeated three times $(n=3)[22-24]$.

Actinomycin-D $(4 \mu \mathrm{M})$, Tamoxifen $(5 \mu \mathrm{M})$ and Anastrozole $(5 \mu \mathrm{M})$ were used as positive controls. Anastrozole is a nonsteroidal inhibitor of aromatase which effectively blocks estrogen synthesis in postmenopausal women and is used as therapy of estrogen receptor-positive breast cancer [23]. So this was selected as standard for estrogen dependent cancer cell line. Tamoxifen may prevent estrogen-independent as well as estrogen-dependent breast cancer by stimulating phospholipase activity and initiating arachidonic acid release. The release of arachidonic acid and/or molecular reactions that accompany that release may initiate pathways that prevent tumor growth [24]. Actinomycin D, one of the oldest anticancer drugs, binds dsDNA (more strongly than dsRNA) and thus inhibits primarily cellular transcription. It is used in the treatment of a variety of tumors [27, 28].

\section{Data presentation and statistical analysis}

All data were compiled from a minimum of three experiments $(n=3)$. Data for statistical analysis were expressed as the mean \pm standard deviation. One-way ANOVA with Dunnett's multiple comparison test was performed using GraphPad Prism version 8 for Windows, to derive statistical significance of each test group to respective control group. Results with $\mathrm{p}<0.05$ were considered as statistically significant.

\section{Identification and characterization of AMB 004 using melting point, FT-IR, Mass, NMR spectroscopy}

AMB 004 was subjected to determination of melting point. Then, it was chemically characterized using various spectroscopic techniques like FT-IR, ESI-MS, ${ }^{1} \mathrm{H}$ NMR spectroscopy. The spectroscopic studies were performed at Sophisticated Analytical Instrumentation Facility, Panjab University, Chandigarh.

\section{Melting point}

Melting point was evaluated for the purified crystals and the values were checked with the literature value.

\section{FT-IR spectroscopy}

The FT-IR spectrum of the compound was recorded, using $\mathrm{KBr}$ pellets, in the range of wave number $4000-250 \mathrm{~cm}^{-1}$, with a resolution of $1 \mathrm{~cm}^{-1}$.

\section{Mass spectroscopy}

The analysis was performed in hybrid quadrupole time of flight mass spectrometer equipped with electrospray ionization (ESI) and atmospheric pressure chemical ionization (APcl) sources having a mass range of $4000 \mathrm{amu}$ and $20000 \mathrm{amu}$ in ToF. The mass to charge 
$(\mathrm{m} / \mathrm{z})$ ratio was recorded in the range of $50-1000 \mathrm{~m} / \mathrm{z}$. The collision energy was $30 \mathrm{eV}$.

\section{NMR spectroscopy}

${ }^{1} \mathrm{H}$ NMR spectra of the compound were recorded on the instrument FT NMR Spectrometer model Avance-II (Bruker) at $400 \mathrm{MHz}$ frequency and 9.4 field strength.

\section{RESULTS}

\section{Bioactivity-guided fractionation}

The direct methanolic extract of $A$. monilifer was investigated for cytotoxic activity against four cancer cell lines. The results indicated the plant possessed very highly significant $(\mathrm{p}<0.001)$ concentrationdependent growth inhibition (up to 95\%) activity in the malignant cells, with the apparent $\mathrm{IC}_{50}$ value with the apparent $\mathrm{IC}_{50}$ values ranging between $100 \mu \mathrm{g} / \mathrm{ml}$ (NRU assay)-200 $\mu \mathrm{g} / \mathrm{ml}$ (MTT assay) (table 1 and 2).

The difference in the apparent $\mathrm{IC}_{50}$ values can be justified by the physiological mechanisms on which these assays are based. As in the MTT assay, tetrazolium salts are reduced to formazan by mitochondrial succinate dehydrogenase, an enzyme which is active only in viable cells with an intact respiratory chain [29]. The uptake of neutral red depends on the lysosomal capacity to maintain $\mathrm{pH}$ gradients through the production of ATP [30].

Table 1: Cytotoxicity activity of AM-1 of $A$. monilifer using MTT assay after $24 \mathrm{hr}$ of treatment

\begin{tabular}{|c|c|c|c|c|c|}
\hline \multirow[t]{2}{*}{ S. No. } & \multirow[t]{2}{*}{ Concentration $(\mu \mathrm{g} / \mathrm{ml})$} & \multicolumn{4}{|c|}{ Percentage of growth inhibition of cancer cells \pm standard deviation } \\
\hline & & MCF 7 & MDA MB 231 & HepG2 & HLE \\
\hline 1 & 10 & $18.23 \pm 1.33$ & $14.66 \pm 2.12$ & $19.34 \pm 2.42$ & $23.29 \pm 3.29^{* *}$ \\
\hline 2 & 25 & $29.12 \pm 2.04 * *$ & $28.49 \pm 3.29 * *$ & $26.34 \pm 3.21^{* *}$ & $14.35 \pm 3.86$ \\
\hline 3 & 50 & $51.77 \pm 4.31^{* * *}$ & $50.85 \pm 3.12^{* * *}$ & $43.14 \pm 2.85^{* *}$ & $44.13 \pm 2.65^{* *}$ \\
\hline 4 & 100 & $54.84 \pm 4.22^{* * *}$ & $54.96 \pm 4.04^{* * *}$ & $50.18 \pm 4.32^{* * *}$ & $20.26 \pm 5.29 * *$ \\
\hline 5 & 200 & $66.35 \pm 3.64^{* * *}$ & $66.49 \pm 4.32^{* * *}$ & $62.33 \pm 2.86^{* * *}$ & $38.32 \pm 3.98^{* *}$ \\
\hline 6 & 300 & $77.54 \pm 4.28^{* * *}$ & $76.18 \pm 5.22^{* * *}$ & $72.14 \pm 3.38^{* * *}$ & $46.20 \pm 2.65^{* *}$ \\
\hline 7 & 400 & $90.17 \pm 5.38^{* * *}$ & $89.38 \pm 4.95^{* * *}$ & $75.83 \pm 4.64^{* * *}$ & $49.39 \pm 7.39 * *$ \\
\hline 8 & 500 & $92.28 \pm 5.97^{* * *}$ & $92.43 \pm 3.45^{* * *}$ & $83.11 \pm 2.65^{* * *}$ & $84.32 \pm 3.39 * * *$ \\
\hline 9 & Vehicle [0.01\% DMSO in culture media] & $2.02 \pm 3.68$ & $2.07 \pm 4.38$ & $1.03 \pm 3.64$ & $2.01 \pm 3.28$ \\
\hline
\end{tabular}

Where statistically (Dunnett's multiple comparison test) ${ }^{*}=$ Significant $(\mathrm{P}<0.05),{ }^{* *}=$ Highly significant $(\mathrm{P}<0.01),{ }^{* * *}=$ Very highly significant $(\mathrm{P}<0.001)$, $(\mathrm{n}=3)$; Data expressed as mean \pm standard deviation

Cytotoxicity experiment was also performed using NRU assay. NRU assay confirmed the results obtained in MTT assay. The results of NRU assay showed that extract inhibited the growth of MDA MB-231 and HepG2 cells. It was found less effective in inhibiting the growth of MCF-7 and HLE cells, unlike MTT assay. IC 50 values for MCF-7 and HLE cells were found to be $200 \mu \mathrm{g} / \mathrm{ml}$ and $300 \mu \mathrm{g} / \mathrm{ml}$, respectively for AM-1 from $A$. monilifer. The results of NRU assay performed for AM-1 is shown in table 2

Table 2: Cytotoxic activity of AM-1 of $A$. monilifer using neutral red uptake assay after $24 \mathrm{~h}$ treatment

\begin{tabular}{|c|c|c|c|c|c|}
\hline \multirow[t]{2}{*}{ S. No. } & \multirow[t]{2}{*}{ Concentration $\mu \mathrm{g} / \mathrm{ml}$} & \multicolumn{4}{|c|}{ Percentage of growth inhibition of cancer cells \pm standard deviation } \\
\hline & & MCF 7 & MDA MB 231 & HepG2 & HLE \\
\hline & 10 & $17.29 \pm 2.41$ & $16.65 \pm 1.87$ & $24.43 \pm 2.48$ & $14.32 \pm 4.72$ \\
\hline 2 & 25 & $37.43 \pm 3.86^{* *}$ & $28.32 \pm 2.86^{* *}$ & $30.29 \pm 2.12^{* *}$ & $24.33 \pm 4.67 *$ \\
\hline 3 & 50 & $41.48 \pm 3.45^{* *}$ & $49.22 \pm 3.76^{* *}$ & $44.54 \pm 3.25^{* *}$ & $38.32 \pm 2.98^{* *}$ \\
\hline 4 & 100 & $37.76 \pm 2.88^{* *}$ & $54.19 \pm 3.14^{* *}$ & $51.55 \pm 3.87^{* *}$ & $33.73 \pm 2.02 *$ \\
\hline 5 & 200 & $50.84 \pm 4.84^{* * *}$ & $64.37 \pm 3.98^{* * *}$ & $62.64 \pm 4.33^{* * *}$ & $39.58 \pm 3.76^{* *}$ \\
\hline 6 & 300 & $51.38 \pm 3.81^{* * *}$ & $75.48 \pm 5.32^{* *}$ & $72.93 \pm 3.54^{* * *}$ & $47.52 \pm 6.48^{* * *}$ \\
\hline 7 & 400 & $61.76 \pm 5.15^{* * *}$ & $90.18 \pm 4.25^{* * *}$ & $77.39 \pm 4.86^{* * *}$ & $71.65 \pm 5.98^{* * *}$ \\
\hline 8 & 500 & $84.54 \pm 6.39^{* * *}$ & $93.37 \pm 4.87^{* * *}$ & $83.32 \pm 4.12^{* * *}$ & $88.47 \pm 7.43^{* * *}$ \\
\hline 9 & Vehicle [0.01\% DMSO in culture media] & $2.59 \pm 2.98$ & $1.87 \pm 3.20$ & $2.39 \pm 3.87$ & $1.29 \pm 3.12$ \\
\hline
\end{tabular}

Where statistically (Dunnett's multiple comparison test) $*=$ Significant $(\mathrm{P}<0.05),{ }^{* *}=$ Highly significant $(\mathrm{P}<0.01),{ }^{* * *}=$ Very highly significant $(\mathrm{P}<0.001),(\mathrm{n}=3)$; Data expressed as mean \pm standard deviation

This preliminary screening revealed that AM-1 from A. monilifer contained chemical constituents capable of exerting cytotoxic activity against cells of selected cancerous cell lines. The apparent $\mathrm{IC}_{50}$ concentration was found to be $200 \mu \mathrm{g} / \mathrm{ml}$, in both the assay methods. It was, thus, decided to screen the fractions obtained from both the extracts at a set concentration of $200 \mu \mathrm{g} / \mathrm{ml}$ to ensure the cytotoxic potential of the respective fraction.

It was thought to isolate biologically active constituents from the plant, possessing cytotoxic activity, which might be responsible for cytotoxic activity of the plants. Bioactivity-guided fractionation approach was adopted for the selection of fractions to be taken up further for isolation of the constituents.

The bioactive direct methanolic extract (AM-1) of the plant was partitioned into Hexane (AM-2), Chloroform (AM-3), Ethyl acetate (AM-4) and Methanolic (AM-5) fractions (fig. 1). Fractions AM-2, AM-3, AM-4 and AM-5 were evaluated for their cytotoxic activities at $200 \mu \mathrm{g} / \mathrm{ml}$ in vitro, using MTT and NRU assays (table 1 and 2).

Table 3: Cytotoxic activity of fractions $(200 \mu \mathrm{g} / \mathrm{ml})$ from $A$. monilifer using MTT assay after $24 \mathrm{~h}$ treatment

\begin{tabular}{lllll}
\hline S. & FRACTION $(\mathbf{2 0 0} \boldsymbol{\mu g} / \mathbf{m l})$ & \multicolumn{2}{l}{ Percentage growth inhibition of cancer cells \pm Standard deviation } \\
\cline { 3 - 5 } No. & & MCF 7 & MDA MB 231 & HepG2 \\
\hline 1 & Hexane (AM-2) & $69.36 \pm 6.42^{* *}$ & $11.61 \pm 2.44$ & $17.41 \pm 1.54$ \\
2 & Ethyl acetate (AM-4) & $76.93 \pm 4.86^{* * *}$ & $71.14 \pm 5.12^{* * *}$ & $69.74 \pm 3.82^{* * *}$ \\
3 & Chloroform (AM-3) & $93.88 \pm 5.64^{* * *}$ & $94.02 \pm 5.88^{* * *}$ & $89.89 \pm 4.82^{* * *}$ \\
4 & Methanol (AM-5) & $65.37 \pm 4.34^{* * *}$ & $42.13 \pm 1.54^{* *}$ & $24.43 \pm 5.12^{*}$ \\
5 & Control & $3.32 \pm 1.54$ & $-1.31 \pm 2.18$ & $19.73 \pm 2.78^{*}$ \\
\hline
\end{tabular}

Where statistically (Dunnett's multiple comparison test $)^{*}=$ Significant $(\mathrm{P}<0.05),{ }^{* *}=$ Highly significant $(\mathrm{P}<0.01), * * *=$ Very highly significant $(\mathrm{P}<0.001),(\mathrm{n}=3)$; Data expressed as mean \pm standard deviation 
Cytotoxic activity of various fractions prepared from AM-1 was performed using NRU assay. The results showed that AM-3 inhibited the growth of MCF-7, MDA MB-231 and HepG2 cells by more than $90 \%$, while it was less effective in inhibiting the growth of HLE cells.
AM-4 showed the almost parallel magnitude of cytotoxic activity on all cell lines. AM-1 showed less than $50 \%$ inhibition to cell growth at selected concentration levels. The results of the studies are shown in table 5.20 .

Table 4: Cytotoxic activity of fractions $(200 \mu \mathrm{g} / \mathrm{ml})$ from $A$. monilifer using neutral red uptake assay after $24 \mathrm{~h}$ treatment

\begin{tabular}{lllll}
\hline S. No. & Fraction $(\mathbf{2 0 0} \boldsymbol{\mu g} / \mathbf{m l})$ & MCF 7 & MDA MB 231 & HepG2 \\
\hline 1 & Hexane (AM-2) & $53.16 \pm 2.88^{* *}$ & $21.39 \pm 3.80^{*}$ & $31.80 \pm 2.66^{*}$ \\
2 & Ethyl acetate (AM-4) & $81.67 \pm 4.86^{* * *}$ & $77.92 \pm 3.26^{* * *}$ & $81.16 \pm 5.28^{* * *}$ \\
3 & Chloroform (AM-3) & $93.81 . \pm 5.84^{* * *}$ & $92.04 \pm 5.86^{* * *}$ & $97.94 \pm 4.86^{* * *}$ \\
4 & Methanol (AM-5) & $46.04 \pm 2.28^{* *}$ & $40.52 \pm 1.86^{* *}$ & $37.29 \pm 2.84^{* *}$ \\
5 & Control & $-0.19 \pm 1.24$ & $5.97 \pm 2.22$ & $37.65 \pm 5.69^{* *}$ \\
\hline
\end{tabular}

Where statistically (Dunnett's multiple comparison test) $*=$ Significant $(\mathrm{P}<0.05),{ }^{* *}=$ Highly significant $(\mathrm{P}<0.01),{ }^{* * *}=$ Very highly significant $(\mathrm{P}<0.001),(\mathrm{n}=3)$; Data expressed as mean \pm standard deviation

The cytotoxic activity was significantly observed in two fractions (AM-3 and AM-4, n=3 for each fraction, mean \pm sd) with similar results obtained with the NRU assay. AM-3 had the maximum effect.

Fractionation of AM-3 of A. monilifer aerial parts (14g) in column chromatography with silica gel employed an isocratic elution system. The eluting solvent was ethyl acetate: hexane: acetone (7:3:5). This resulted in the isolation of a triterpenoidal compound AMB 004.

Triterpenes are naturally occurring organic compounds, characterized by a high diversity of chemical structure and biological properties. They are becoming increasingly significant in the treatment of cancer due to their efficacy and safety. The anticancer triterpenoid saponins enable the inhibition of cancer formation and progression by various mechanisms like apoptosis, autophagy, etc. [31-33]

Keeping all the above facts in mind, it was thought worthwhile to identify the triterpenoid in AM-3, which may be responsible for the cytotoxicity of the plant.

\section{Spectral characteristics of isolated compound (AMB 004)}

A $28 \mathrm{mg}$ white powder of AMB 004 was isolated. For structure elucidation of this AMB 004, spectral analysis of the powder was done; the results of which are summarized in table 1 .

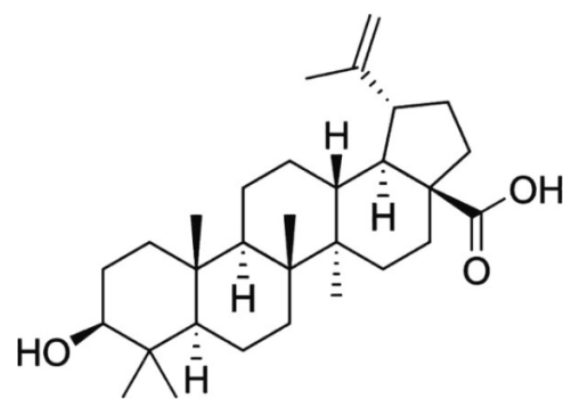

Fig. 3: Chemical structure of betulinic acid

Table 5: Spectral characteristics of isolated triterpenoidal compound (AMB 004)

\begin{tabular}{|c|c|c|c|c|}
\hline S. No. & Parameter & \multicolumn{2}{|l|}{ Values } & References \\
\hline 1. & Yield & \multicolumn{2}{|l|}{$\begin{array}{l}\text { A white powder } \\
28 \mathrm{mg}\end{array}$} & \\
\hline 2. & $\mathrm{Rf}$ & \multicolumn{2}{|c|}{$\begin{array}{l}\text { 1. } 0.22 \text { [petroleum ether: ethyl acetate: toluene }(7: 2: 1)] \\
\text { 2. } 0.62 \text { [Ethyl acetate: Hexane }(7: 3) \text { ] }\end{array}$} & 19,32 \\
\hline 3. & Melting point & \multicolumn{2}{|l|}{$295-299^{\circ} \mathrm{C}$} & \\
\hline 4. & IR (KBr) & $\begin{array}{l}\text { Wave number }\left(\mathbf{c m}^{-1}\right) \\
3442 \\
2943 \\
1685 \\
1451 \\
883\end{array}$ & $\begin{array}{l}\text { Characteristic of:- } \\
\text { Presence of hydroxyl function (-OH) } \\
-\mathrm{CH} 3 \text { and-CH2 asymmetric and symmetric vibrations } \\
\mathrm{C}-\mathrm{O} \text { stretching } \\
\text { O-H bending vibrations } \\
\text { Vibration of- } \mathrm{CH} 2 \text { in alkene group }\end{array}$ & 33,34 \\
\hline 5. & ${ }^{1} \mathrm{H} \mathrm{NMR}\left(\mathrm{CDCl}_{3}\right)$ & \multicolumn{2}{|c|}{$\begin{array}{ll}\text { - } & 0.65,0.77,0.98,1.14 \text { and } 1.34(5 \mathrm{~s}, 15 \mathrm{H}, \text { all tertiary-CH3), } \\
\text { - } & 1.37(\mathrm{~m}, 2 \mathrm{H}, \mathrm{H}-21) \\
\text { - } & 1.45(\mathrm{~m}, 2 \mathrm{H}, \mathrm{H}-\mathrm{H}-\mathrm{H}-\mathrm{H}) \\
\text { - } & 1.51(\mathrm{~m}, 4 \mathrm{H}, \mathrm{H}-18, \mathrm{H}-19 \text { and } \mathrm{H}-15) \\
\text { - } & 2.09(\mathrm{~m}, 3 \mathrm{H}, \mathrm{H}-1 \text { and } \mathrm{H}-9) \\
\text { - } & 2.13(\mathrm{~m}, 2 \mathrm{H}, \mathrm{H}-14) \\
\text { - } & 3.17(\mathrm{t}, 2 \mathrm{H}, \mathrm{J}=7 \mathrm{~Hz}, \mathrm{H}-2) \\
\text { - } & 3.38(\mathrm{~s}, 2 \mathrm{H}, \mathrm{H}-7) \\
\text { - } & 4.56(\mathrm{~s}, 2 \mathrm{H}, \mathrm{H}-11) \\
\text { - } & 4.59(\mathrm{~s}, 2 \mathrm{H}, \mathrm{H}-12)\end{array}$} & 33,34 \\
\hline 6. & $\begin{array}{l}\text { Mass } \\
\text { spectroscopy (ESI- } \\
\text { MS) }\end{array}$ & \multicolumn{2}{|c|}{$\begin{array}{l}-\mathrm{M}+=457.51 \\
\text { Other fragments at m/z } 438[\mathrm{M}-\mathrm{H} 2 \mathrm{O}], 411[\mathrm{M}-\mathrm{COOH}], 248[\mathrm{C} 16 \mathrm{H} 24 \mathrm{O} 2], 203[248-\mathrm{COOH}], 220 \\
{[\mathrm{C} 15 \mathrm{H} 24 \mathrm{O}], 203[220-\mathrm{OH}], 175[220-\mathrm{COOH}], 207[\mathrm{C} 14 \mathrm{H} 23 \mathrm{O}], 189[207-\mathrm{H} 2 \mathrm{O}]}\end{array}$} & 33,34 \\
\hline
\end{tabular}

The above I. R., ${ }^{1} \mathrm{H}-\mathrm{NMR}$ and ESI-MS spectral data and their comparison with those described in literatures $[19,37,38]$, revealed that probable structure of compound AMB 004 may be Betulinic acid (fig. 3). 


\section{Cytotoxic activity of isolated compound AMB 004}

From the above studies, it was found that betulinic acid is highly regarded for its cytotoxic properties due to its structural properties [39]. Also, the incidences of liver cancer and breast cancer are increasing over the time. In fact, these are the most common cancer types in some countries. Therefore the effectiveness of betulinic acid was investigated for the aforementioned cancer types.

Preliminary screening of organic fractions against four cancer cell lines revealed the most potent cytotoxic fraction for the medicinal plant. Further assessment of these potent fractions highlighted that out of all the fractions, the fraction containing this compound (betulinic acid) has significant anticancer activity.

Compound AMB 004 was evaluated for cytotoxic activity against four cancer cell lines (MCF-7, MDA MB 231, HepG2 and HLE). In this study, eight serial dilutions $(0.78,1.56,3.12,6.25,12.5,25,50,100$ $\mu \mathrm{M}$ ) of each compound containing DMSO (maximum: $0.01 \%$ ) were prepared in $200 \mu \mathrm{l}$ media as a final concentration in the well. Cytotoxic activity of compound AMB 004 was evaluated at $24 \mathrm{hr}$ and $48 \mathrm{hr}$ in order to establish a time as well as concentrationdependent cytotoxic effect.

Actinomycin-D $(4 \mu \mathrm{M})$, Tamoxifen $(5 \mu \mathrm{M})$ and Anastrozole $(5 \mu \mathrm{M})$ were used as positive controls. For each cell line, a density of 1 x $10^{4}$ cells per well in $100 \mu \mathrm{l}$ aliquots of medium was seeded into 96well cell culture plates. The cells were allowed to attach for $24 \mathrm{hr}$ at
$3{ }^{\circ} \mathrm{C}, 5 \% \mathrm{CO}_{2}$ in air in a humidified atmosphere. The next day, the serial dilutions of compound AMB 004 were added.

Vehicle control groups received the same amount of DMSO (maximum: 0.01\%). After a $24 \mathrm{hr}$ and $48 \mathrm{hr}$ drug exposure time, the toxic endpoints were determined. For each treatment, five replicate wells were examined, and each experiment was repeated three times $(n=3)$. Results were calculated as percentage growth inhibition, untreated (control) cells versus treated cells according to the formula as described previously (MTT assay). Mean and standard deviation was calculated between the three experiments.

The results from the MTT assay showed that statistically significant $(\mathrm{P}<0.01)$ inhibition $(20-21 \%)$ of breast cancer cell MCF-7 started at a concentration of $6.24 \mu \mathrm{M}$, which became highly significant $(\mathrm{p}<0.001)$ at a concentration of $25 \mu \mathrm{M}$ for MCF-7 cells after $24 \mathrm{hr}$ treatment with Betulinic acid (table 6); while for MDA MB-231 cells, a highly significant inhibition $(\mathrm{p}<0.001)$ was observed at $50 \mu \mathrm{M}$ (table 6). After a prolonged exposure to $48 \mathrm{~h}$, the percentage inhibition was not much increased in MDA MB-231 (table 8). While in MCF 7 cells, \% inhibition was increased to $85 \%$ at a concentration of $12.48 \mu \mathrm{M}$, then subsequently showing a very highly significant inhibition of $98 \%$ at a concentration of $100 \mu \mathrm{M}$. Therefore, a selective growth inhibition of cancer cells by Betulinic acid was observed for the oestrogen dependent cancer cell line (MCF-7), while this triterpene could not retard the growth effectively in the estrogen independent cancer cells (MDA MB-231), where highly significant inhibition of $67 \%$ was observed at a concentration of $50 \mu \mathrm{M}$ after $48 \mathrm{~h}$. (table 8)

Table 6: Cytotoxic activity of betulinic acid from A. monilifer against four cancer cell lines using MTT assay after $24 \mathrm{~h}$ treatment

\begin{tabular}{|c|c|c|c|c|c|}
\hline S. No. & Betulinic acid $(\mu \mathrm{M})$ & MCF 7 & MDA MB 231 & HepG2 & HLE \\
\hline 1 & 0.78 & $4.57 \pm 3.18$ & $4.18 \pm 3.87$ & $12.67 \pm 3.12$ & $4.29 \pm 3.28$ \\
\hline 2 & 1.56 & $9.80 \pm 4.32$ & $5.78 \pm 5.98$ & $12.76 \pm 2.93$ & $5.29 \pm 2.82$ \\
\hline 3 & 3.12 & $7.59 \pm 2.45$ & $13.20 \pm 2.78$ & $20.43 \pm 6.45^{*}$ & $13.89 \pm 2.27$ \\
\hline 4 & 6.24 & $21.46 \pm 4.33^{*}$ & $12.44 \pm 2,87$ & $23.45 \pm 4.23^{*}$ & $12.87 \pm 3.76$ \\
\hline 5 & 12.48 & $34.38 \pm 2.97^{* *}$ & $20.42 \pm 5.40^{*}$ & $50.64 \pm 6.33^{* * *}$ & $20.11 \pm 4.12 *$ \\
\hline 6 & 25.0 & $96.56 \pm 7.19^{* * *}$ & $25.55 \pm 3.84 *$ & $78.88 \pm 8.92^{* * *}$ & $24.98 \pm 5.54 *$ \\
\hline 7 & 50.00 & $98.12 \pm 5.48^{* * *}$ & $52.41 \pm 2.93^{* * *}$ & $80.10 \pm 8.92^{* * *}$ & $53.21 \pm 6.76^{* * *}$ \\
\hline 8 & 100.00 & $98.32 \pm 6.43^{* * *}$ & $61.90 \pm 7.38^{* * *}$ & $88.34 \pm 6.34^{* * *}$ & $60.27 \pm 4.34^{* * *}$ \\
\hline 9 & Actinomycin D 5 $\mu \mathrm{M}$ & $83.88 \pm 8.92^{* * *}$ & $65.76 \pm 8.59^{* * *}$ & $57.78 \pm 7.12^{* * *}$ & $66.16 \pm 6.18^{* * *}$ \\
\hline 10 & Tamoxifen $5 \mu \mathrm{M}$ & $83.98 \pm 9.89^{* * *}$ & $27.65 \pm 10.23^{*}$ & -- & -- \\
\hline 11 & Anastrozole $5 \mu \mathrm{M}$ & $50.72 \pm 6.78^{* * *}$ & $70.21 \pm 12.40^{* * *}$ & --- & -- \\
\hline 12 & Vehicle control & $0.54 \pm 3.85$ & $4.25 \pm 3.44$ & $1.48 \pm$ & $2.07 \pm 2.43$ \\
\hline
\end{tabular}

Where statistically (Dunnett's multiple comparison test) ${ }^{*}=$ Significant $(\mathrm{P}<0.05),{ }^{* *}=$ Highly significant $(\mathrm{P}<0.01),{ }^{* * *}=$ Very highly significant $(\mathrm{P}<0.001)$, $(\mathrm{n}=3)$; Data expressed as mean \pm standard deviation

Table 7: Cytotoxic activity of betulinic acid from $A$. monilifer against four cancer cell lines using neutral red uptake assay after $24 \mathrm{~h}$ treatment

\begin{tabular}{|c|c|c|c|c|c|}
\hline S. No. & Betulinic acid $(\mu \mathrm{M})$ & MCF 7 & MDA MB 231 & HepG2 & HLE \\
\hline 1 & 0.78 & $3.76 \pm 4.39$ & $4.86 \pm 1.29$ & $14.78 \pm 4.23$ & $4.26 \pm 2.13$ \\
\hline 2 & 1.56 & $5.66 \pm 1.87$ & $6.14 \pm 2.39$ & $23.74 \pm 8.65^{* *}$ & $6.58 \pm 3.18$ \\
\hline 3 & 3.12 & $8.69 \pm 4.23$ & $9.87 \pm 4.22$ & $40.42 \pm 3.77^{* *}$ & $9.12 \pm 3.22$ \\
\hline 4 & 6.24 & $21.92 \pm 3.12^{*}$ & $13.79 \pm 3.12^{*}$ & $56.59 \pm 4.58^{* *}$ & $20.95 \pm 4.52^{* *}$ \\
\hline 5 & 12.48 & $43.54 \pm 4.23^{* *}$ & $16.98 \pm 3.67^{* * *}$ & $71.69 \pm 8.92^{* * *}$ & $16.28 \pm 1.87$ \\
\hline 6 & 25.0 & $68.81 \pm 2.18^{* * *}$ & $27.99 \pm 4.29 * * *$ & $81.25 \pm 3.95^{* * *}$ & $28.18 \pm 5.12^{*}$ \\
\hline 7 & 50.00 & $70.24 \pm 3.77^{* * *}$ & $52.19 \pm 2.76^{* * *}$ & $84.14 \pm 5.94^{* * *}$ & $51.64 \pm 4.87^{* *}$ \\
\hline 8 & 100.00 & $85.63 \pm 8.92^{* * *}$ & $68.82 \pm 6.33^{* * *}$ & $99.75 \pm 6.46^{* * *}$ & $66.65 \pm 2.64^{* * *}$ \\
\hline 9 & Actinomycin D, $5 \mu \mathrm{M}$ & $90.88 \pm 7.43^{* * *}$ & $89.14 \pm 3.12^{* * *}$ & $65.12 \pm 4.23^{* *}$ & $87.28 \pm 6.19^{* * *}$ \\
\hline 10 & Tamoxifen $5 \mu \mathrm{M}$ & $78.43 \pm 5.96^{* * *}$ & $38.48 \pm 8.73^{* * *}$ & -- & -- \\
\hline 11 & Anastrozole $5 \mu \mathrm{M}$ & $46.42 \pm 4.23^{* *}$ & $74.32 \pm 9.23^{* * *}$ & -- & -- \\
\hline 12 & Vehicle control & $-2.68 \pm 2.33$ & $0.11 \pm 4.30$ & $1.32 \pm 2.93$ & $2.11 \pm 2.11$ \\
\hline
\end{tabular}

Where statistically (Dunnett's multiple comparison test) ${ }^{*}=$ Significant $(\mathrm{P}<0.05),{ }^{* *}=$ Highly significant $(\mathrm{P}<0.01),{ }^{* * *}=$ Very highly significant $(\mathrm{P}<0.001),(\mathrm{n}=3)$; Data expressed as mean \pm standard deviation

The inhibition can be further justified with the NRU assay. The results showed that significant inhibition started early at $6.24 \mu \mathrm{M}$ for MCF-7 cells after $24 \mathrm{hr}$ exposure and exhibited a very highly significant effect $(68 \%)$ at as little as $25 \mu \mathrm{M}$ (table 7), which increased very significantly after 48 h i.e. $97 \%$ at $100 \mu \mathrm{M}$ (table 9). In case of estrogen independent breast cancer cells (MDA MB-231), the highly significant effect of $52 \%$ was observed at $50 \mu \mathrm{M}$ after 24 hr (table 7), but this inhibition increased slightly to $65 \%$ inhibition calculated after $48 \mathrm{~h}$ (table 9).

Results showed that a significant inhibition $(21 \%)$ was achieved at $6.24 \mu \mathrm{M}$ in HLE cells; similarly HepG2 cells achieved a significant 
inhibition (23\%) was achieved at $1.56 \mu \mathrm{M}$ itself (table 7). All the above results are with respect to untreated cells (control). The cytotoxic effect on HepG2 was observed at a very low concentration
$(1.56 \mu \mathrm{M})$ with neutral red uptake assay after $48 \mathrm{hr}$ treatment (table 9), while that can be seen to be increased to a highly significant activity of $65 \%$ at $50 \mu \mathrm{M}$ in HLE cells (table 9).

Table 8: Cytotoxic activity of Betulinic acid from A. monilifer against four cancer cell lines using MTT assay after $48 \mathrm{~h}$ treatment

\begin{tabular}{|c|c|c|c|c|c|}
\hline S. No. & Betulinic acid $(\mu \mathrm{M})$ & MCF 7 & MDA MB 231 & HepG2 & HLE \\
\hline 1 & 0.78 & $4.87 \pm 2.14$ & $5.72 \pm 2.18$ & $6,86 \pm 1.19$ & $5.28 \pm 2.32$ \\
\hline 2 & 1.56 & $5.12 \pm 3.01$ & $13.64 \pm 2.72$ & $13.87 \pm 2.49$ & $12.98 \pm 2.65$ \\
\hline 3 & 3.12 & $6.88 \pm 3.13$ & $16.75 \pm 3.27$ & $45.76 \pm 3.83^{* * *}$ & $15.98 \pm 3.82$ \\
\hline 4 & 6.24 & $37.81 \pm 4.28 * *$ & $12.76 \pm 2.39$ & $60.21 \pm 4.72^{* * *}$ & $11.96 \pm 3.17$ \\
\hline 5 & 12.48 & $85.54 \pm 5.38^{* * *}$ & $17.97 \pm 2.41$ & $88.12 \pm 5.33^{* * *}$ & $16.54 \pm 3.73$ \\
\hline 6 & 25.0 & $98.53 \pm 6.43^{* * *}$ & $29.88 \pm 2.83^{* *}$ & $95.21 \pm 5.98^{* * *}$ & $28.92 \pm 4.12^{*}$ \\
\hline 7 & 50.00 & $97.65 \pm 6,39^{* * *}$ & $67.12 \pm 4.49^{* * *}$ & $95.93 \pm 6.12^{* * *}$ & $66.59 \pm 4.56^{* * *}$ \\
\hline 8 & 100.00 & $98.13 \pm 5.89^{* * *}$ & $77.97 \pm 4.25^{* * *}$ & $98.54 \pm 5.29 * * *$ & $75.19 \pm 4.71^{* * *}$ \\
\hline 9 & Actinomycin D $4 \mu \mathrm{M}$ & $78.45 \pm 4.19^{* * *}$ & $87.32 \pm 5.39^{* * *}$ & $90.49 \pm 4.83^{* * *}$ & $87.26 \pm 5.05^{* * *}$ \\
\hline 10 & Tamoxifen $5 \mu \mathrm{M}$ & $98.54 \pm 3.63^{* * *}$ & $87.42 \pm 6.58^{* * *}$ & -- & $86.79 \pm 4.97^{* * *}$ \\
\hline 11 & Anastrozole $5 \mu \mathrm{M}$ & $47.34 \pm 2.87^{* *}$ & $44.86 \pm 3.29^{* *}$ & -- & $46.96 \pm 2.28^{* *}$ \\
\hline 12 & Vehicle control & $4.71 \pm 2.21$ & $2.65 \pm 2.11$ & $1.6 \pm 1.21$ & $2.07 \pm 3.11$ \\
\hline
\end{tabular}

Where statistically (Dunnett's multiple comparison test $)^{*}=$ Significant $(\mathrm{P}<0.05),{ }^{* *}=$ Highly significant $(\mathrm{P}<0.01),{ }^{* * *}=$ Very highly significant $(\mathrm{P}<0.001),(\mathrm{n}=3)$; Data expressed as mean \pm standard deviation

Table 9: Cytotoxic activity of Betulinic acid from $A$. monilifer against four cancer cell lines using Neutral Red Uptake assay after 48 h treatment

\begin{tabular}{|c|c|c|c|c|c|}
\hline S. No. & Betulinic acid $(\mu \mathrm{M})$ & MCF 7 & MDA MB 231 & HepG2 & HLE \\
\hline 1 & 0.78 & $12.14 \pm 2.52$ & $6.48 \pm 3.52$ & $8.50 \pm 2.19$ & $6.32 \pm 3.11$ \\
\hline 2 & 1.56 & $14.23 \pm 2.93$ & $11.25 \pm 2.83$ & $20.87 \pm 2.76^{*}$ & $10.97 \pm 2.27$ \\
\hline 3 & 3.12 & $27.97 \pm 3.84^{*}$ & $14.34 \pm 2.09$ & $54.78 \pm 2.79^{* *}$ & $13.98 \pm 3.92 *$ \\
\hline 4 & 6.24 & $54.98 \pm 4.12^{* * *}$ & $24.97 \pm 2.95^{*}$ & $63.94 \pm 3.11^{* * *}$ & $25.01 \pm 2.87^{* *}$ \\
\hline 5 & 12.48 & $98.56 \pm 5.81^{* * *}$ & $28.18 \pm 3.27^{*}$ & $96.94 \pm 5.39^{* * *}$ & $27.76 \pm 3.22^{* *}$ \\
\hline 6 & 25.0 & $99.13 \pm 5.39 * * *$ & $35.55 \pm 4.73^{* *}$ & $97.45 \pm 6.75^{* * *}$ & $34.85 \pm 3.17^{* *}$ \\
\hline 7 & 50.00 & $97.18 \pm 5.72^{* * *}$ & $65.94 \pm 4.38^{* * *}$ & $98.12 \pm 5.73^{* * *}$ & $65.16 \pm 4.29^{* * *}$ \\
\hline 8 & 100.00 & $97.43 \pm 6.82^{* * *}$ & $79.38 \pm 5.17^{* * *}$ & $99.51 \pm 7.12^{* * *}$ & $78.28 \pm 6.82^{* * *}$ \\
\hline 9 & Actinomycin D $4 \mu \mathrm{M}$ & $98.93 \pm 5.44^{* * *}$ & $88.21 \pm 6.19^{* * *}$ & $96.67 \pm 6.49^{* * *}$ & $87.48 \pm 7.21^{* * *}$ \\
\hline 10 & Tamoxifen $5 \mu \mathrm{M}$ & $99.63 \pm 5.29 * * *$ & $62.98 \pm 4.49^{* * *}$ & -- & -- \\
\hline 11 & Anastrozole $5 \mu \mathrm{M}$ & $35.89 \pm 3.29 * *$ & $91.59 \pm 5.26^{* * *}$ & -- & -- \\
\hline 12 & Vehicle control & $1.52 \pm 1.55$ & $4.31 \pm 3.28$ & $3.17 \pm 1.35$ & $2.54 \pm 3.28$ \\
\hline
\end{tabular}

Where statistically (Dunnett's multiple comparison test $)^{*}=$ Significant $(\mathrm{P}<0.05),{ }^{* *}=$ Highly significant $(\mathrm{P}<0.01),{ }^{* * *}=$ Very highly significant $(\mathrm{P}<0.001),(\mathrm{n}=3)$; Data expressed as mean \pm standard deviation

\section{DISCUSSION}

Medicinal Plants have a long history of use in the treatment of cancer. Plants have formed the basis for traditional medicine systems, which have been used for thousands of years in countries such as China [41], India and Pakistan [42, 43]. Hartwell, in his review of plants used against cancer, lists more than 3000 plant species that have reportedly been used in the treatment of cancer [44]. An impressive number of anticancer drugs have been isolated or derived from medicinal plants, are currently in clinical practice, based on their folklore use [45].

Cancer chemotherapy plays a significant role in the treatment of many malignancies, either curative or palliative care, depending upon the specific tumour condition [46]. The main objective of any cancer chemotherapy is to kill cancer cells with as little damage as possible to normal cells [47].

These results indicate all the two plants possess very highly significant $(\mathrm{P}<0.001)$ concentration-dependent growth inhibition (up to 95\%) activity in the malignant cells (as shown in Tables 1 and 2), with the apparent $\mathrm{IC}_{50}$ values ranging between $100 \mu \mathrm{g} / \mathrm{ml}$ (MTT assay) $-200 \mu \mathrm{g} / \mathrm{ml}$ (NRU assay).

The difference in the apparent $\mathrm{IC}_{50}$ values can be justified by the physiological mechanisms on which these assays are based. As in the MTT assay, tetrazolium salts are reduced to formazan by mitochondrial succinate dehydrogenase, an enzyme which is active only in viable cells with an intact respiratory chain [29].

The uptake of neutral red depends on the lysosomal capacity to maintain $\mathrm{pH}$ gradients through the production of ATP [30]. The weakly cationic dye penetrates cell membranes by non-ionic passive diffusion enabling a proton gradient to maintain a $\mathrm{pH}$ lower than that of cytoplasm. Thus, the dye becomes charged and retained inside the Iysosomes of metabolically active cells, characterizing the neutral red uptake assay as a more sensitive technique, differentiating between the dead and metabolically active cells that have a tendency to proliferate in the cultured cell population [48].

A serial dilution of eight concentrations $(0.78,1.56,3.12,6.25,12.5,25$, $50,100 \mu \mathrm{M}$ ) for isolated compound AMB 004 was tested using two cell viability assays (MTT and Neutral Red Uptake assays) for $24 \mathrm{hr}$ and 48 hr treatments. Three positive controls were used: Actinomycin-D ( $4 \mu \mathrm{M}$, inhibitor of protein synthesis), Tamoxifen (5 $\mu \mathrm{M}$, oestrogen receptor antagonist) and Anastrozole ( $5 \mu \mathrm{M}$, aromatase inhibitor).

AMB 004 was isolated from the chloroform fraction of the methanolic extract of $A$. monilifer. AMB 004 showed a highly significant selective growth inhibition against oestrogen dependent breast cancer cells (MCF-7) and HepG2, while in MDA MB-231cells, moderate cytotoxic activity was observed. The results of MTT and neutral red uptake assays for percentage inhibition of cell growth over a concentration range for the four cancer cell lines, after $24 \mathrm{hr}$ and $48 \mathrm{~h}$ are summarized in Tables 6 to 9. Cytotoxicity studies of Betulinic acid from A. monilifer against HLE and HepG2 cells indicated that this triterpene possessed more cytotoxic activity for hepatic carcinoma cells (HepG2 and HLE cells) as compared to breast cancer cells (MCF-7 and MDA MB-231) and that too more specifically for HepG2 cells.

The various results of MTT assay suggest that betulinic acid (isolated from A. monilifer) might be damaging the respiratory chain 
in mitochondria of cells by apoptosis, which leads to decreased formation of NADPH [49]. NADPH is responsible for the expression of oxidoreductase enzymes i.e. succinate dehydrogenase in Mitochondria. This oxidoreductase enzyme reduces yellow coloured MTT dye to blue colored crystals of Formazan. The amount of Formazan formed is the measure of mitochondria of viable cells. This resultant blue coloured Formazan was measured from the absorbance in the visible range. [40]

The triterpene (Betulinic acid) isolated in this study is novel for this plant. The triterpene is reported for the first time in the genus and the plant, as well. Also, no activity on tumour cells has been reported yet for the plant.

\section{CONCLUSION}

The results from the present study are in agreement with the ethnobotanical or traditional use of $A$. monilifer against cancer growth. The current research work has established that the cytotoxic activity of the plant against MCF-7, MDA-MB-231, HLE and HepG2 cells was highly significant with $90 \%$ growth inhibition. A triterpene, Betulinic acid, was isolated from the aerial parts of $A$. monilifer. The cytotoxic activity of the plant can be attributed to Betulinic acid. It is the first report of isolation of betulinic acid from the Alysicarpus species.

\section{ACKNOWLEDGMENT}

The authors are grateful to Ramanbhai Patel College of Pharmacy, CHARUSAT and Shivam Education and Research Foundation Trust for providing necessary facilities to carry out the work.

\section{FUNDING}

This research did not receive any specific grant from funding agencies in the public, commercial, or not-for-profit sectors.

\section{AUTHORS CONTRIBUTIONS}

Purvi Kakrani, Harish Kakrani, and Manan Raval contributed to the design and implementation of the research, to the analysis of the results and the writing of the manuscript.

\section{CONFLICT OF INTERESTS}

Declared none

\section{REFERENCES}

1. Chavan AR, Oza GM. The flora of pavagadh. Vadodara: Department of Botany, M. S. University of Baroda; 1966.

2. Shah GL. Flora of gujarat state. $1^{\text {st }}$ Edn. Part I. Vallabh vidyanagar: Sardar Patel University Press; 1978.

3. Guha Bakshi DN. Flora of Murshidabad district West Bengal, India. Jodhpur: Scientific Publishers; 1984.

4. Rao RR, Haridasan K. An ethnobotanical survey of medicinal and other useful plants from North-East India. J Econ Tax Bot 1991;15:423-36.

5. Jain P, Sahu TR. An ethnobotanical study of noradehi sanctuary park of Madhya Pradesh, India: Native plant remedies for scorpion sting and snakebite. J Econ Tax Bot 1993;17:315-28.

6. Radhakrishnan $\mathrm{K}$, Pandurangan AG, Pushpangadan $\mathrm{P}$ Sasidharan A. Less known ethnomedicinal plants of Kerala state and their conservation. Ethnobotany 1996;8:82-4.

7. Sankaranarayanan AS. Folklore medicines for jaundice from Coimbatore and palghat districts of Tamil Nadu and Kerala, India. Ancient Sci Life 1988;7:175-9.

8. Mitchell SA. The jamaican root tonics: a botanical reference. Focus Altern Complement Ther 2011;16:271-80.

9. Sikarwar RLS, Kaushik JP. Folk medicines of morena district, Madhya Pradesh, India. Int J Pharmacogn 1993;31:283-7.

10. Singh KK, Prakash A. Indigenous phytotherapy among the gond tribes of Uttar Pradesh, India. Ethnobotany 1994;6:37-41.

11. Anonymous. Reviews on indian medicinal plants. Vol. 2. New Delhi: ICMR; 2004.

12. Kumari M, Rao G, Padmaja V. Role of vitexin and isovitexin in hepatoprotective effect of Alysicarpus monilifer linn against $\mathrm{CCl}_{4}$ induced hepatotoxicity. Phytopharmacol 2012;3:273-85.
13. Riaz N, Anis I, Khan P, Shah R, Malik A. Alysinol-a new triterpene from Alysicarpus monolifer. Nat Prod Lett 2003;16:415-8.

14. Kakrani PH, Kakrani BH, Kakrani HN. Isolation of stigmasterol and ursolic acid from methanolic extract of aerial parts of Alysicarpus monilifer L. (DC.) (papilionaceae). Pharma Sci Mon 2012;3:2185-91.

15. Kakrani P, Kakrani H, Saluja A. Pharmacognostic evaluation of aerial parts of Alysicarpus monilifer L. (Dc.). Int J Pharm Pharm Sci 2011(a);3:128-34.

16. Kakrani P, Kakrani H, Saluja A. Evaluation of anti-inflammatory activity of methanolic extract of the aerial parts of Alysicarpus monilifer L. (DC.). J Pharm Res 2011(b);4:3529-20.

17. Kakrani P, Kakrani H, Saluja A. Evaluation of analgesic activity of methanolic extract of the aerial parts of Alysicarpus monilifer L.(DC.). Pharma Sci Mon 2011(c):2078-84.

18. Karthikeyan K. Antidiabetic activities of Alysicarpus monilifer in streptozotocin-induced diabetic rats. Ph. D Thesis. Tamil Nadu: Annamalai University; 2017.

19. Hossain MA, Ismail Z. Isolation and characterization of triterpenes from the leaves of Orthosiphon stamineus. Arab J Chem 2013;6:295-8.

20. Harborne J. Phytochemical methods. $2^{\text {nd }}$ Edn. London: Chapan and Hall Ltd; 1973.

21. Fotakis G, Timbrell A. In vitro cytotoxicity assays: Comparison of LDH, neutral red, MTT and protein assay in hepatoma cell lines following exposure to cadmium chloride. Toxicol Lett 2006;160:171-7.

22. Borenfreund E, Babich H, Martin-Alguacil N. Comparisons of two in vitro cytotoxicity assays-the neutral red (NR) and tetrazolium MTT tests. Toxicol In Vitro 1988;2:1-6.

23. Naik SB, Deshpande SR. Cytotoxicity of stem extracts of selected cassia species against hela and breast cancer cell lines in vitro. Asian J Pharm Clin Res 2017;10:80-2.

24. Kakrani PH, Kakrani HN, Raval M. Cytotoxic effect of Corchorus depressus against HepG2 and HLE human liver cancer cells. Asian J Pharm Clin Res 2018;11:187-9.

25. Miller WR. Aromatase inhibitors: mechanism of action and role in the treatment of breast cancer. Semin Oncol 2003;30(4, Suppl 14):3-11.

26. Levine L. Tamoxifen and the rafoxifene analog LY117018: their effects on arachidonic acid release from cells in culture and on prostaglandin $\mathrm{I}_{2}$ production by rat liver cells. BMC Cancer 2004;13:4-49.

27. Avendano C, Menendez JC. Anticancer drugs acting via radical species, photosensitizers and photodynamic therapy of cancer. In: Avendano C, Menendez JC. Medicinal Chemistry of Anticancer Drugs. Elsevier; 2008.

28. Waheeda A, Barbara J, Barton SJ, Khan GM, Najm-Us-Saqib $\mathrm{Q}$, Hussain M, et al. Novel acylated steroidal glycosides from Caralluma tuberculata induced caspase-dependent apoptosis in cancer cells. J Ethnopharmacol 2011;137:1189-96.

29. Green DR, Kroemer G. The pathophysiology of mitochondrial cell death. Science 2004;305:626-9.

30. Winckler J. Vital staining of lysosomes and other organelles of the rat with neutral red. Prog Histochem Cytochem 1974;6:1-89.

31. Chudzik M, Korzonek Szlacheta I, Krol W. Triterpenes as potentially cytotoxic compounds. Molecules 2015;20:1610-25.

32. Petronelli A, Gaetano P, Ugo T. Triterpenoids as new promising anticancer drugs. Anti Cancer Drugs 2009;20:880-9.

33. Du JR, Long FY, Chen C. Research progress on natural triterpenoid saponins in the chemoprevention and chemotherapy of cancer. Enzymes 2014;36:95-130.

34. Wagner $H$, Bladt S. Plant drug analysis: a thin layer chromatography atlas. $2^{\text {nd }}$ edn. New York: Springer Verlag Berlin Heidelberg; 2011.

35. Silverstein RM, Webster FX. Spectrometric identification of organic compounds. $6^{\text {th }}$ Edn. New Delhi: Wiley India Pvt. Ltd; 2009.

36. William Kemp. Organic spectroscopy. Pennsylvania State University: Macmillan; 1991.

37. Cichewicz RH, Kouzi SA. Chemistry, biological activity, and chemotherapeutic potential of betulinic acid for the prevention 
and treatment of cancer and HIV infection. Med Res Rev 2004;24:90-114.

38. Haque ME, Shekhar HU, Mohamad AU, Rahman H, Mydul Islam AKM, Hossain MS. Triterpenoids from the stem bark of Avicennia officinalis. Dhaka University J Pharma Sci 2006;12:53-7.

39. Mukherjee R, Kumar V, Srivastava SK, Agarwal SK, Burman AC. Betulinic acid derivatives as anticancer agents: structureactivity relationship. Anti Cancer Agents Med Chem 2006; 6:271-9.

40. Aslanturk OS. In vitro cytotoxicity and cell viability assays: principles, advantages and disadvantages. In: Larramendy ML, Soloneski S. Genotoxicity-a predictable Risk to our actual world. London: IntechOpen limited; 2017. p. 1-17.

41. Chang HM, But PPH. Pharmacology and applications of chinese materia medica. Singapore: World Scientific Publishing; 1986.

42. Kapoor LD. CRC handbook or ayurvedic medicinal plants. Boca Raton, USA: CRC Press; 1990.
43. Wei L, Brossi A, Susan L, Bastow KF, Lee K. Antitumor agents 248-chemistry and antitumor activity of tylophorine-related alkaloids. Studies Natl Prod Chem Elsevier 2008;34:3-34.

44. Hartwell JL. Plants used against cancer. Massachusetts: Quarterman Publications; 1982.

45. Cragg G, Newmann DJ. Biodiversity: a continuing source or novel drug leads. Pure Appl Chem 2005;77:7-24.

46. Carter Jr WH, Wampler GL, Stabelien DM, Campbell ED. Drug activity and therapeutic synergism in cancer treatment. Cancer Res 1982;42:2963-71.

47. Halliwell B, Gutteridge JMC. Free radicals in biology and medicine. $2^{\text {nd }}$ Edn. Oxford, UK: Charendon Press; 1988.

48. Repetto G, Del Peso A, Zurita JL. Neutral red uptake assay for the estimation of cell viability/cytotoxicity. Nat Protoc 2008;3:1125-31.

49. Feng C, Ma W, Song Y, Guo Q, Wu Q, Zheng W. Detection of cell apoptosis by MTT assay. Di Yi Jun Yi Da Xue Xue Bao 2002;22:262-3. 